УДК 631.95:633.17: (477.7)

(C) 2017

Свиридова Л. А., старший викладач

Рожкков А. О., доктор сільськогосподарських наук

Харківський національний аграрний університет ім. В. В. Докучаєва

\title{
ОЦІНКА РОЗВИТКУ ПОСІВІВ СОРГО ЗЕРНОВОГО ЗА ФЕНОЛОГІЧНИМИ СПОСТЕРЕЖЕННЯМИ
}

\section{Рецензент - доктор сільськогосподарських наук Г. І. Яровий}

\begin{abstract}
Висвітлено результати чотирирічних досліджень щчодо впливу технологічних чинників: способів сівби та норм висіву на час проходження окремих фаз розвитку рослин сорго зернового. У дослідах доведено вплив циих чинників на варіабельність тривалості проходження досліджуваних фаз росту $і$ розвитку рослин.

Iз послабленням иченотичної напруги у посівах за рахунок застосування широкорядного способу сівби з міжряддями 45 см і норм висіву насіння 120 i 160 тис. ит./га відзначено прискорене проходження посівами сорго зернового фази трубкування. Разом із тим зменшення конкурентної боротьби в посівах рослин за оптимізації способу сівби та зменшення норми висіву, навпаки, приводило до "розтягування» фази кущіння та міжфазного періоду формуванняналивання зерна, шзо сприяло повнішому використанню агроресурсу та формуванню вищої врожайності зерна рослин. Відмічені закономірності проявлялися в усі роки досліджень.
\end{abstract}

Ключові слова: сорго зернове, норма висіву, спосіб сівби, абіотичні чинники, фенологічні фази, иенотична напруга, онтогенез.

Постановка проблеми. Формування високопродуктивних посівів зернових культур - складний багатостадійний процес закономірних змін росту і розвитку рослин, у якому бере участь велика кількість екзогенних і ендогенних чинників, що «регламентують» рівень розкриття генетичного потенціалу продуктивності рослин.

Протягом онтогенезу в рослинах поетапно відбуваються генетично зумовлені закономірні зміни, які базуються на послідовній реалізації програми розвитку рослин. Дослідження зв'язку між тривалістю етапів росту і розвитку рослин, 3 одного боку, і агротехнічних чинників вирощування - 3 другого, дасть можливість управляти продукційним процесом посівів сорго зернового.

Аналіз останніх досліджень і публікацій, у яких започатковано розв'язання проблеми. Під час вирощування сорго зернового формування оптимальної густоти стеблостою і рівномірний його розподіл по посівній площі з урахуванням морфологічних особливостей певного сорту чи гібрида часто має вирішальне значення для формування високої врожайності рослин [3].

Із нормами висіву та способами сівби рослин тісно пов'язані такі важливі фізіологічні функції, як фотосинтетична діяльність, інтенсивність транспірації, водоспоживання, дихання тощо. Ці технологічні чинники також значною мірою визначають мікроклімат у посівах, біологічні процеси в грунті, характер поширення та ступінь шкоди, яку завдають хвороби та шкідники. Коригуючи густоту та рівномірність розподілу рослин по площі живлення, можна значною мірою регулювати швидкість проходження фенофаз росту і розвитку рослин, інтенсивність їх кущіння, синхронність розвитку рослин і дозрівання зерна [6].

За оцінкою строків настання фенофаз розвитку можна проводити біологічний контроль за ростом і розвитком рослин [4]. Відомо, що динаміка формування врожаю залежить від етапів органогенезу і фенологічних фаз розвитку рослин [7].

3 тривалістю вегетаційного періоду тісно пов'язані морфологічні та біологічні показники й особливості реалізації генетичної програми конкретного сорту (гібрида) рослин. Мінливість погодних умов під час формування та наливання зерна, а також різна тривалість фенологічних фаз розвитку рослин значною мірою можуть впливати і на якісні показники вирощуваної продукції [5]. Дослідження швидкості росту і розвитку гібридів сорго в онтогенезі залежно від комплексної дії абіотичних $\mathrm{i}$ агротехнічних чинників дасть можливість визначити найважливіші залежності процесу реалізації генетичної програми рослин і максимальної іiі реалізації.

Елементи технології вирощування мають різний характер впливу на інтенсивність проходження фенологічних фаз росту і розвитку рослин сорго. Так, науковець Є. А. Блохіна [1] зазначає, що система живлення фактично не має впливу на тривалість міжфазних періодів до фази трубкування, тоді як рівень густоти посівів і характер їх розподілу по площі живлення вже 3 початку росту й розвитку рослин сорго помітно 


\section{СІЛЬСЬКЕ ГОСПОДАРСТВО. РОСЛИННИЦТВО}

впливають на швидкість проходження окремих фенологічних фаз.

Мета досліджень полягала у визначенні зв'язку між складовими елементами технології вирощування, які відображають рівень ценотичної напруги в посівах рослин (норми висіву та способи сівби), і тривалістю проходження рослинами окремих фенологічних періодів. Визначення тісноти зв'язку між тривалістю фенологічних фаз розвитку рослин і елементами технології дасть змогу значною мірою пояснити варіаційні розбіжності ознак продуктивності гібридів сорго зернового в досліджуваних варіантах.

Методика досліджень. Дослідження проведено протягом 2007-2009, 2012 рр. на дослідному полі ХНАУ ім. В. В. Докучаєва за загальноприйнятою методикою [2].

Багатофакторний дослід закладали методом розщеплених ділянок. Ділянками першого порядку (чинник А) були два гібриди сорго зернового: 1 - Степовий 8 (контроль); 2 - Даш Е. Ділянками другого порядку (чинник В) були два широкорядних способи сівби з міжряддями 45 i 70 см. Елементарними ділянками в досліді (чинник С) виступали чотири варіанти норми висіву насіння: 120, 160, 200 і 240 тис. шт./га. Облікова площа елементарної ділянки досліду -20 м². Кількість повторень у досліді - чотириразова.

Грунт дослідного поля - чорнозем типовий важкосуглинковий на карбонатному лесі. В орному шарі грунту міститься гумусу 4,4-4,7 \%, рухливого фосфору (за Чириковим) - 138 мг/кг, калію - 103 мг/кг грунту.

Район проведення досліджень характеризується нестабільними умовами зволоження. У різні роки кількість опадів за вегетацію рослин значно коливалася в той чи інший бік від середньобагаторічного показника. Кращі умови зволоження були в погодних умовах 2008 р.

Температурні показники періоду вегетації рослин сорго за роками досліджень відрізнялися від середньобагаторічних показників. Значні розбіжності за основними метеорологічними показниками у роки досліджень дали можливість повніше визначити вплив досліджуваних елементів технології вирощування на ріст і розвиток рослин, зокрема на польову схожість насіння та виживаність рослин досліджуваних гібридів сорго.

Результати досліджень. За результатами проведеної оцінки тривалості фенофаз розвитку гібридів сорго зернового залежно від норми висіву насіння і характеру його розподілу по посівній площі встановлено розбіжності, які вказують на різний характер формування посівів із самого початку їх становлення.
Аналіз впливу досліджуваних технологічних чинників не виявив істотного їх впливу на мінливість тривалості фази сходів і трьох-чотирьох листків. Істотний вплив норм висіву і способів сівби спостерігався від фази кущіння рослин. Фаза кущіння відіграє важливу роль у формуванні високопродуктивних посівів, оскільки в цю фазу утворюються фітомери колосового стрижня.

У проведених дослідженнях тривалість фази кущіння гібридів сорго зернового на варіантах широкорядного способі сівби 3 міжряддями 45 см була довшою, ніж на посівах широкорядного способу сівби з міжряддями 70 см і залежно від норм висіву і погодних умов становила 15-22 днів у гібрида Степовий 8 і 17-22 днів - у гібрида Даш Е (табл. 1). На широкорядних посівах 3 міжряддями 70 см цей період був меншим і становив від 13 до 20 днів у гібрида Степовий 8 i від 15 до 21 днів - у гібрида Даш Е. Вплив способів сівби на тривалість фази кущіння більшою мірою проявлявся в рослин гібрида Даш Е, що свідчить про більшу реакцію цього гібрида на оптимізацію способу сівби. Зокрема, розбіжність між показниками тривалості фази кущіння за впливу способів сівби в гібридів Степовий 8 i Даш Е становила відповідно один і два дні.

Серед досліджуваних агротехнічних чинників більший вплив на мінливість фази кущіння мала норма висіву. Зокрема, діапазон варіабельності тривалості цієї фази за впливу норми висіву насіння становив два дні в гібрида Степовий 8 і три дні в гібрида Даш Е. Збільшення різниці між тривалістю фази кущіння більшою мірою проявлялося в разі підвищення норми висіву 3200 до 240 тис. шт./га. Наприклад, у гібрида Даш Е з підвищенням норми висіву насіння 3120 до 200 тис. шт./га (на два кроки градації - 80 тис. шт./га) тривалість фази кущіння «розтягувалася» лише на один день, тоді як 3 підвищенням норми висіву насіння 3200 до 240 тис. шт./га (на один крок градації) - на два дні.

Домінуючим чинником щодо варіабельності часу проходження фази кущіння були погодні умови вегетаційного періоду. Так, тривалість цієї фази у гібрида Степовий 8 у середньому за нормами висіву та способами сівби варіювала від 20 днів у 2008 р. до 14 днів у 2009 р., а в гібрида Даш Е - від 19 днів у 2007 р. до 16 днів у 2009 р. Відсутність аналогії між показниками часу проходження фази кущіння досліджуваних гібридів за роками досліджень обумовлена різною тривалістю періодів вегетації цих гібридів, унаслідок чого процес їхнього кущіння за календарними строками не збігався, тож погодні умови проходження цієї фази відрізнялися. 
СІЛЬСЬКЕ ГОСПОДАРСТВО. РОСЛИННИЦТВО

\section{1. Тривалість фази кущіння гібридів сорго зернового залежсно від впливу норм висіву, способів сівби та погодних умов, днів}

\begin{tabular}{|c|c|c|c|c|c|c|}
\hline \multirow{2}{*}{$\begin{array}{c}\text { Спосіб } \\
\text { сівби } \\
\text { (чинник B) }\end{array}$} & \multirow{2}{*}{$\begin{array}{c}\text { Норма висіву, } \\
\text { тис. нас./га } \\
\text { (чинник } C \text { ) }\end{array}$} & \multicolumn{4}{|c|}{ Рік досліджень (чинник $D$ ) } & \multirow{2}{*}{$\begin{array}{c}\text { Середнє за } \\
\text { роками }\end{array}$} \\
\hline & & 2007 & 2008 & 2009 & 2012 & \\
\hline \multicolumn{7}{|c|}{$\begin{array}{c}\text { Чинник } \boldsymbol{A} \text { (гібриди): } \\
\text { Степовий } 8 \\
\end{array}$} \\
\hline \multirow{4}{*}{$I^{*}$} & 120 & 19 & 17 & 17 & 22 & 19 \\
\hline & 160 & 19 & 17 & 16 & 21 & 18 \\
\hline & 200 & 18 & 17 & 16 & 21 & 18 \\
\hline & 240 & 17 & 18 & 15 & 20 & 18 \\
\hline \multirow{4}{*}{ II } & 120 & 18 & 19 & 14 & 20 & 18 \\
\hline & 160 & 17 & 20 & 14 & 19 & 18 \\
\hline & 200 & 15 & 20 & 14 & 19 & 17 \\
\hline & 240 & 15 & 21 & 13 & 18 & 17 \\
\hline \multirow{4}{*}{$\begin{array}{c}\text { Середнє за } \\
\text { чинником } C\end{array}$} & 120 & 19 & 18 & 16 & 21 & 19 \\
\hline & 160 & 18 & 19 & 15 & 20 & 18 \\
\hline & 200 & 17 & 19 & 15 & 20 & 18 \\
\hline & 240 & 16 & 19 & 14 & 19 & 17 \\
\hline \multirow{2}{*}{$\begin{array}{c}\text { Середнє за } \\
\text { чинником } B\end{array}$} & I & 18 & 17 & 16 & 21 & 18 \\
\hline & II & 16 & 20 & 14 & 19 & 17 \\
\hline \multicolumn{7}{|c|}{ Даш E } \\
\hline \multirow{4}{*}{$I^{*}$} & 120 & 22 & 19 & 19 & 21 & 20 \\
\hline & 160 & 21 & 19 & 18 & 21 & 20 \\
\hline & 200 & 21 & 19 & 18 & 20 & 20 \\
\hline & 240 & 20 & 18 & 17 & 19 & 19 \\
\hline \multirow{4}{*}{ II } & 120 & 21 & 17 & 18 & 19 & 19 \\
\hline & 160 & 20 & 17 & 17 & 18 & 18 \\
\hline & 200 & 19 & 17 & 16 & 18 & 18 \\
\hline & 240 & 18 & 16 & 15 & 16 & 16 \\
\hline \multirow{4}{*}{$\begin{array}{l}\text { Середнє за } \\
\text { чинником } C\end{array}$} & 120 & 22 & 18 & 19 & 20 & 20 \\
\hline & 160 & 21 & 18 & 18 & 20 & 19 \\
\hline & 200 & 20 & 18 & 17 & 19 & 19 \\
\hline & 240 & 19 & 17 & 16 & 17 & 17 \\
\hline \multirow{2}{*}{$\begin{array}{c}\text { Середнє за } \\
\text { чинником } B\end{array}$} & I & 21 & 19 & 18 & 20 & 20 \\
\hline & II & 19 & 17 & 16 & 18 & 18 \\
\hline
\end{tabular}

* Широкорядний спосіб сівби: I- міжряддя 45 см; II-міжряддя 70 см.

Тривалість фази кущіння має велике значення для розкриття потенціалу продуктивності посівів: чим більша ії тривалість, тим краща основа для формування вищої врожайності рослин за сприятливих умов подальшого їх розвитку. Тому за цим показником беззаперечна перевага широкорядного способу сівби 3 міжряддями 45 см і менших норм висіву насіння - 120-200 тис. шт./га. До цього слід додати, що саме на посівах 3 міжряддями 45 см ефект впливу норми висіву на тривалість фази кущіння був значно меншим, тобто діапазон можливого вибору норм висіву за більш рівномірного розподілу рослин за площею живлення значно більший, і навпаки, - 3 відхи- ленням площі живлення у бік від оптимальної рослини сильніше реагували на норми висіву насіння, через що мінливість часу фази кущіння на таких посівах за впливу норми висіву проявлялася значно більше.

Зовсім інша тенденція впливу досліджуваних технологічних чинників відмічена під час аналізу тривалості фази виходу рослин у трубку. Зокрема, зменшення рівня ценотичної напруги в посівах прискорювало проходження цієї фази росту і розвитку (табл. 2). У фазу трубкування відбувається лише розростання міжвузлів стебла i не формуються нові елементи генеративної сфери рослин, тож під час вирощування сорго на 


\section{СІЛЬСЬКЕ ГОСПОДАРСТВО. РОСЛИННИЦТВО}

зерно нас цікавить скоріше проходження цієї фази, оскільки від іï тривалості рівень урожайності фактично не залежить.

За аналогією з фазою кущіння, у фазу виходу рослин у трубку більший вплив на іiі тривалість мали норми висіву насіння. Так, діапазон розбіжності між показниками часу фази виходу рослин у трубку за впливу норми висіву насіння у середньому за роками досліджень і способами сівби у гібрида Даш Е становив три дні, тоді як за впливу способів сівби - лише один день. Важливо додати, що, як і під час аналізу тривалості фази кущіння, значно сильніше тривалість фази виходу в трубку за дії досліджуваних норм висі- ву змінювалася в гібрида сорго зернового Даш Е, що свідчить про важливість правильного підбору варіантів технології вирощування для нього.

Аналіз тривалості періоду формування і достигання зернівки показав різницю між досліджуваними варіантами складових елементів технології вирощування. Зі зменшенням конкурентної боротьби між рослинами, що відбувається під час зменшення норми висіву насіння та наближення форми площі живлення рослин до квадратної, відмічається подовження вказаного міжфазного періоду, що позитивно впливає на підвищення врожайності рослин, оскільки вивільняється більше часу на наливання зерна.

\section{2. Тривалість фази виходу в трубку гібридів сорго зернового залежно від впливу норм висіву, способів сівби та погодних умов, днів}

\begin{tabular}{|c|c|c|c|c|c|c|}
\hline \multirow{2}{*}{$\begin{array}{c}\text { Спосіб } \\
\text { сівби } \\
\text { (чинник } B \text { ) }\end{array}$} & \multirow{2}{*}{$\begin{array}{c}\text { Норма висіву, } \\
\text { тис. нас./га } \\
\text { (чинник } C \text { ) }\end{array}$} & \multicolumn{4}{|c|}{ Рік досліджень (чинник $D$ ) } & \multirow{2}{*}{$\begin{array}{c}\text { Середнє за } \\
\text { роками }\end{array}$} \\
\hline & & 2007 & 2008 & 2009 & 2012 & \\
\hline \multicolumn{7}{|c|}{$\begin{array}{c}\text { Чинник А (гібриди): } \\
\text { Степовий } 8\end{array}$} \\
\hline \multirow{4}{*}{$I^{*}$} & 120 & 19 & 20 & 17 & 20 & 19 \\
\hline & 160 & 19 & 20 & 17 & 21 & 19 \\
\hline & 200 & 19 & 21 & 18 & 22 & 20 \\
\hline & 240 & 20 & 21 & 19 & 23 & 21 \\
\hline \multirow{4}{*}{ II } & 120 & 18 & 21 & 18 & 22 & 20 \\
\hline & 160 & 18 & 20 & 19 & 23 & 20 \\
\hline & 200 & 19 & 21 & 19 & 23 & 20 \\
\hline & 240 & 21 & 20 & 20 & 24 & 21 \\
\hline \multirow{4}{*}{$\begin{array}{c}\text { Середнє за } \\
\text { чинником } C\end{array}$} & 120 & 19 & 21 & 18 & 21 & 20 \\
\hline & 160 & 19 & 20 & 18 & 22 & 20 \\
\hline & 200 & 19 & 21 & 19 & 23 & 20 \\
\hline & 240 & 21 & 21 & 20 & 24 & 21 \\
\hline \multirow{2}{*}{$\begin{array}{c}\text { Середнє за } \\
\text { чинником } B\end{array}$} & I & 19 & 21 & 18 & 22 & 20 \\
\hline & II & 19 & 21 & 19 & 23 & 21 \\
\hline \multicolumn{7}{|c|}{ Гібрид Даш Е } \\
\hline \multirow{4}{*}{$\mathrm{I}^{*}$} & 120 & 18 & 16 & 16 & 20 & 18 \\
\hline & 160 & 18 & 17 & 16 & 20 & 18 \\
\hline & 200 & 18 & 18 & 17 & 20 & 18 \\
\hline & 240 & 19 & 19 & 18 & 22 & 20 \\
\hline \multirow{4}{*}{ II } & 120 & 18 & 18 & 17 & 21 & 19 \\
\hline & 160 & 18 & 19 & 18 & 21 & 19 \\
\hline & 200 & 18 & 19 & 18 & 22 & 19 \\
\hline & 240 & 20 & 21 & 20 & 23 & 21 \\
\hline \multirow{4}{*}{$\begin{array}{c}\text { Середнє за } \\
\text { чинником } C\end{array}$} & 120 & 18 & 17 & 17 & 21 & 18 \\
\hline & 160 & 18 & 18 & 17 & 21 & 19 \\
\hline & 200 & 18 & 19 & 18 & 21 & 19 \\
\hline & 240 & 20 & 20 & 19 & 23 & 21 \\
\hline \multirow{2}{*}{$\begin{array}{c}\text { Середнє за } \\
\text { чинником } B\end{array}$} & I & 18 & 18 & 17 & 21 & 19 \\
\hline & II & 19 & 19 & 18 & 22 & 20 \\
\hline
\end{tabular}

* Широкорядний спосіб сівби: I - міжряддя 45 см; II - міжряддя 70 см. 


\section{СІЛЬСЬКЕ ГОСПОДАРСТВО. РОСЛИННИЦТВО}

В обох досліджуваних гібридів максимальна тривалість періоду формування і достигання зерна (39 днів) відмічена на варіантах широкорядного способу сівби 3 міжряддями 45 см і нормою висіву насіння 120 і 160 тис. шт./га (табл. 3). Зі збільшенням норми висіву насіння до 240 тис. шт./га тривалість досліджуваного періоду в середньому за способами сівби і по роках досліджень скорочувалася на два дні. За аналогією з раніше проаналізованими фазами розвитку рослин, вплив способів сівби на тривалість періоду формування та достигання зерна був більшим у гібрида Даш Е.

Збільшення періоду формування та достигання зерна досліджуваних гібридів сорго за умови зменшення норми висіву насіння та оптимізації форми площі живлення рослин відмічено в усі роки досліджень, однак ефективність їх була різною. Тобто можна стверджувати про ефект взаємодії досліджуваних агротехнічних і абіотичних чинників. Вплив норм висіву насіння і способів сівби більшою мірою проявлявся в погодних умовах 2007 р. Наприклад, розбіжність між показниками тривалості періоду наливання та достигання зерна гібрида Даш Е в погодних умовах вегетаційного періоду 2007 р. становила чотири дні, тоді як у 2008, 2009 і 2012 рр. - два дні.

Як і в попередні досліджувані фази росту i розвитку рослин, більший вплив на мінливість часу формування і достигання зерна сорго зернового мали погодні умови вегетаційного періоду.

\section{3. Тривалість періоду формування і достигання зернівки гібридів сорго залежно від впливу норм висіву, способів сівби і погодних умов, днів}

\begin{tabular}{|c|c|c|c|c|c|c|}
\hline \multirow{2}{*}{$\begin{array}{c}\text { Спосіб } \\
\text { сівби } \\
\text { (чинник } B \text { ) }\end{array}$} & \multirow{2}{*}{$\begin{array}{c}\text { Норма висіву, } \\
\text { тис. нас./га } \\
\text { (чинник } C \text { ) }\end{array}$} & \multicolumn{4}{|c|}{ Рік досліджень (чинник $D$ ) } & \multirow{2}{*}{$\begin{array}{c}\text { Середнє за } \\
\text { роками }\end{array}$} \\
\hline & & 2007 & 2008 & 2009 & 2012 & \\
\hline \multicolumn{7}{|c|}{$\begin{array}{c}\text { Чинник } \boldsymbol{A}(\text { (гібриди): } \\
\text { Степовий } 8\end{array}$} \\
\hline \multirow{4}{*}{$I^{*}$} & 120 & 40 & 42 & 37 & 38 & 39 \\
\hline & 160 & 40 & 41 & 37 & 37 & 39 \\
\hline & 200 & 38 & 41 & 36 & 37 & 38 \\
\hline & 240 & 37 & 40 & 35 & 36 & 37 \\
\hline \multirow{4}{*}{ II } & 120 & 39 & 41 & 36 & 36 & 38 \\
\hline & 160 & 37 & 40 & 35 & 35 & 37 \\
\hline & 200 & 36 & 40 & 35 & 35 & 37 \\
\hline & 240 & 35 & 39 & 34 & 33 & 35 \\
\hline \multirow{4}{*}{$\begin{array}{l}\text { Середнє за } \\
\text { чинником } C\end{array}$} & 120 & 40 & 42 & 37 & 37 & 39 \\
\hline & 160 & 39 & 41 & 36 & 36 & 38 \\
\hline & 200 & 37 & 41 & 36 & 36 & 38 \\
\hline & 240 & 36 & 40 & 35 & 35 & 36 \\
\hline \multirow{2}{*}{$\begin{array}{c}\text { Середнє за } \\
\text { чинником } B \\
\end{array}$} & I & 39 & 41 & 36 & 37 & 38 \\
\hline & II & 37 & 40 & 35 & 35 & 37 \\
\hline \multicolumn{7}{|c|}{ Гібрид Даш Е } \\
\hline \multirow{4}{*}{$I^{*}$} & 120 & 40 & 44 & 36 & 37 & 39 \\
\hline & 160 & 40 & 43 & 36 & 37 & 39 \\
\hline & 200 & 38 & 42 & 36 & 37 & 38 \\
\hline & 240 & 37 & 40 & 35 & 35 & 37 \\
\hline \multirow{4}{*}{ II } & 120 & 37 & 41 & 34 & 35 & 37 \\
\hline & 160 & 36 & 40 & 34 & 35 & 36 \\
\hline & 200 & 35 & 40 & 34 & 35 & 36 \\
\hline & 240 & 33 & 38 & 33 & 33 & 34 \\
\hline \multirow{4}{*}{$\begin{array}{l}\text { Середне за } \\
\text { чинником } C\end{array}$} & 120 & 39 & 43 & 35 & 36 & 38 \\
\hline & 160 & 38 & 42 & 35 & 36 & 38 \\
\hline & 200 & 37 & 41 & 35 & 36 & 37 \\
\hline & 240 & 35 & 39 & 34 & 34 & 36 \\
\hline \multirow{2}{*}{$\begin{array}{c}\text { Середнє за } \\
\text { чинником } B\end{array}$} & I & 39 & 42 & 36 & 37 & 38 \\
\hline & II & 35 & 40 & 34 & 35 & 36 \\
\hline
\end{tabular}


Діапазон мінливості досліджуваного показника в обох гібридів за впливу погодних умов у середньому за нормами висіву та способами сівби становив п'ять днів - від 41 дня у 2008 р. до 35 днів у 2009 р. (табл. 3).

Висновок. У результаті досліджень встановлено рівень впливу норм висіву, способів сівби та погодних умов вегетаційного періоду на тривалість проходження окремих фаз росту і розвитку гібридів сорго зернового.

Ефект досліджуваних технологічних чинників в усі роки проведення досліджень починав про-

\section{БІБЛІОГРАФІЯ}

1. Блохина Е. А. Продуктивность гибридов сорго в зависимости от сроков посева и условий питания в северо-восточном регионе Беларуси : автореф. дис. ... к. с.-х. н. : спец. 06.01.09. «Растениеводство» / Е. А. Блохина. - Горки, 2016. $25 \mathrm{c}$.

2. Доспехов Б. А. Методика полевого опыта (с основами статистической обработки результатов исследований) / Б. А. Доспехов. - М. : Агропромиздат, 1985. $-305 \mathrm{c}$.

3. Крылов А. В., Филатов В. И. Продуктивность и основные показатели фотосинтетической деятельности зернового сорго в зависимости от нормы сева / А. В. Крылов, В. И. Филатов // Кукуруза и сорго. - 2002. - №3. - С. 21-24.

4. Куперман Ф. М., Чирков Ю. И. Биологичес- являтися з фази кущіння, коли починає зростати конкурентна боротьба між рослинами.

Загальною закономірністю впливу способів сівби та норм висіву на тривалість фази виходу в трубку є іï скорочення у результаті послаблення ценотичної напруги між рослинами в посівах при зменшенні норм висіву насіння та звуженні ширини міжрядь 370 до 45 см і, відповідно, збільшення тривалості періодів кущіння і формування-достигання зерна за дії цих же варіантів дослідних чинників. Відмічена закономірність проявлялася в усі роки досліджень.

кий контроль за развитием растений на метеорологических станциях (микрофенология) / Ф. М. Куперман, Ю. И.Чирков. - Ленинград, 1970. - 215 с.

5. Рудник-Іващенко О. I. Просо. Особливості біології, фізіології, генетики: [монографія] / О. І. Рудник-Іващенко. - Інститут цукрових буряків, УААН. - К. : Колобіг, 2009. - 160 с.

6. Царев А. П. Влияние способов и густоты посева на продуктивность зернового сорго Пищевое 614 в условиях Саратовской области / А. П. Царев, В. Ф. Королев, Т. Г. Хусенетдинова // Кукуруза и сорго. - 2000. - №6. - С. 19-20.

7. Hänsel $H$. Physiologie der Ertragsbildung und die Züchtung auf Ertrag bei Getreide / H. Hänsel // Z. für Pflanzenzüchtung. - 1965. - P. 54. 